\title{
Cement Plugging for Exclusion of Bottom Water in the Augusta Field, Kansas
}

\author{
BY H. F. SAIDEL, ${ }^{*}$ AUGUSTA, KANS.
}

(New York Meeting, February, 1919)

THIS paper summarizes the results obtained from the preliminary cementing of wells in an effort to cut off the bottom water. The object of this work was two-fold:

(1) To prevent the oil sand from becoming flooded.

(2) To plug off bottom water, thereby preserving the individual well and reclaiming production.

Valuable suggestions and help have been given by the following named: Messrs. Kyle and La Velle, of the U. S. Bureau of Mines; Magnolia Petroleum Co.; Freed Oil and Gas Co. The cementing work was carried out under the personal supervision of L. J. Snyder.

In an unpublished paper on the "Water Problem in the Augusta Field," S. K. Clark reaches the following conclusions:

(1) That the great amount of water present is bottom water, occurring in the Varner sand, the main producing or the 2500 -ft. horizon.

(2) That the only striking connection between structure and water is in the area of the marked fault on the Ralston, E. C. Varner, and F. Varner leases in sections $8,9,16$ and 17.

(3) That the oil occurs in porous streaks, generally separated by finegrained, well cemented sand, which is barren. Possibly two or three such pay streaks may be found. That under a pay, fine-grained sand occurs, which is presumably barren at the time of drilling, but soon reveals water.

The writer takes partial exception to the last point, because well defined shale, slate, lime, or hard sand breaks have been encountered in a great many cases, separating the pay streaks under which water is often found. This is not an invariable occurrence, as cases have been noted when the oil has been followed immediately by water in the same stratum.

In an effort to overcome the water menace, the following methods of plugging were tried:

(1) Plugging with wood, lead, and limit plugs.

(2) Plugging with sand pumpings.

* Resident Geologist, Empire Gas and Fuel Co. 
(3) Mudding the sand, removing the packer, and driving a limit plug.

(4) Cementing.

A few variations of the last process will be discussed on the following pages. The success obtained by the above methods has been variable. In some places the plugging has been remarkably successful temporarily, as in the early efforts on wells of the Penley lease. In a few instances, as Brown No. 4, Sec. 16, the plugging was decidedly effective in improving both the cemented well and the surrounding ones.

\section{Moyle No. 4, Sec. 10}

This well produced a large percentage of water for some time. A limit plug was driven at the bottom of the well but proved unsatisfactory. In driving the plug through the shalelime break much matcrial was broken off, thus forming an imperfect seal. It was then decided to cement. A trip bailer was constructed (Fig. 1) and enough cement was put in the well to fill it to the top of the break. This cementing sealed the hole with material having practically the same character as the shale-lime formation.

The cement was allowed ample time (14 days) to set before the well was pumped. The results of this test were satisfactory, as can be seen from the relative percentages of oil, B.S., and water produced before and after cementing (Table 1).

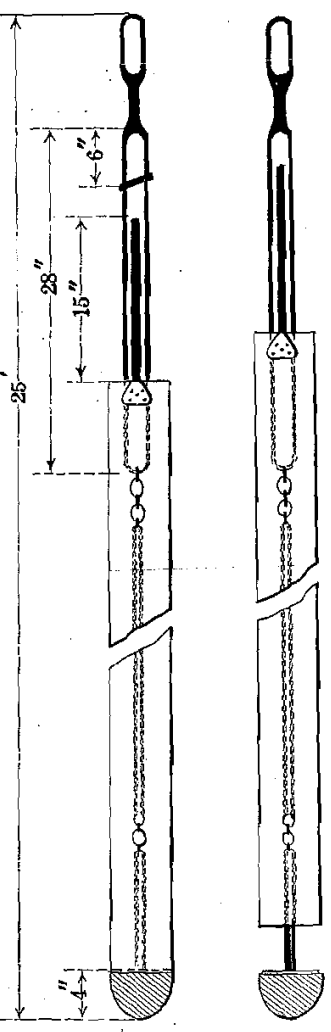

Before Dumping After Dumping FIG. 1.-DETAIL OF TRIP BAILER.

Table 1.-Moyle No. 4, Sec. 10

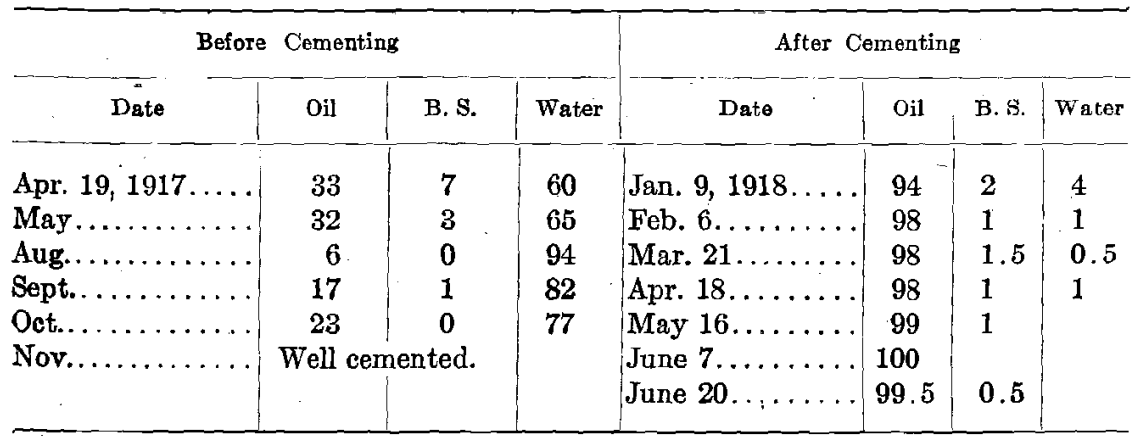


Brant No. 3, Sec. 2, Twp. 28 S., R. 4 E.

The cementing of this well proved so unsatisfactory that it was drilled out and re-cemented. Drilling out and cementing was done three times during one week. Other methods were tried, in an effort to shut off bottom water temporarily. A packer was placed but failed to work, although sufficient mud had been forced in to shut off the water. The cement was then put in on top of the mud and a limit plug was driven

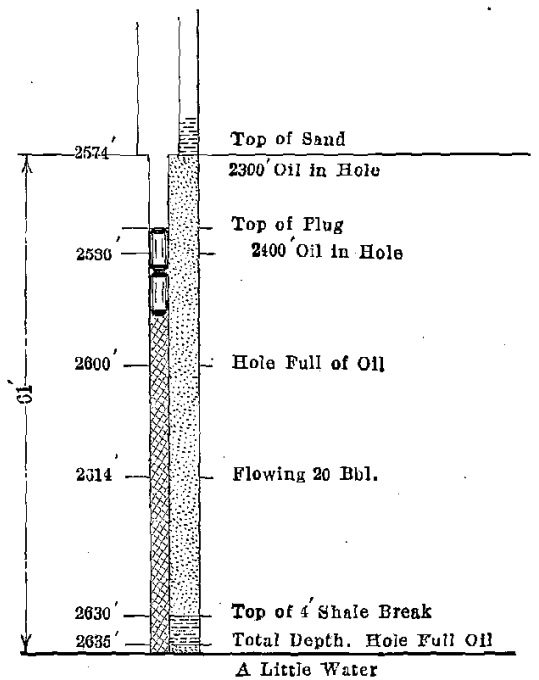

Fig. 2.-Brant No. 3. Cement, limit plugs and character of sand When DRILIING IN.

into it; a second limit plug was then driven on top of the first. This job has been successful, as shown by the behavior of the well before and after (Table 2).

TABLE 2.--Brant No. 3, Sec. 2

\begin{tabular}{|c|c|c|c|c|c|c|c|}
\hline \multicolumn{4}{|c|}{ Before Cementing } & \multicolumn{4}{|c|}{ After Cementing } \\
\hline Date & Oil & B. $\mathbf{s}$. & Water & Date & Oil & B. $s$. & Water \\
\hline Apr., $1917 \ldots \ldots$ & 18 & 2 & 80 & Feb. $21,1918 \ldots$ & 20 & .. & 80 \\
\hline May............ & 19 & 4 . & 77 & Feb. 23....... & 16 & $\because$ & 84 \\
\hline Sept... . . . . & 9 & . . & 91. & Feb. 25.... & 8.1 & 1 & 91 \\
\hline Oct...... & 15 & . & 85 & Apr. 19. & \multicolumn{3}{|c|}{$\begin{array}{l}\text { Well cemented } \\
\text { again. }\end{array}$} \\
\hline Nov............ & 11 & .. & 89 & May $17 \ldots$ & 44 & 4 & 52 \\
\hline Jan. 22, 1918. . . & Plugged & with ceme & & May 23.. & 70 & 25 & $5.0^{*}$ \\
\hline & & & & June 20 : & 80 & 14 & 6 \\
\hline
\end{tabular}

* Average of 10 -min. tests. 
Scully No. 6, Sec. 28

This well was cemented to the top of a shale break and a limit plug was driven in the top of the green cement. The well was put to pumping, three days after cementing, with unsatisfactory results. The relative percentages of oil, B. S., and water were as shown in Table 3 .

TABLE 3.--Scully No. 6, Sec. 28

\begin{tabular}{|c|c|c|c|c|c|c|c|}
\hline \multicolumn{4}{|c|}{ Before Cementing } & \multicolumn{4}{|c|}{ After Cementing } \\
\hline Date & Oil & B. S, & Water & Date & Oil & B. $\mathbf{s .}$ & Water \\
\hline $\begin{array}{l}\text { Aug. } 4,1917 \ldots \ldots \\
\text { Sept. } 21 \ldots \ldots \ldots \\
\text { Oct. } 15 \ldots \ldots \ldots \\
\text { Feb. } 8,1918 \ldots \ldots \\
\text { Mar. } 25, \ldots \ldots \ldots\end{array}$ & $\begin{array}{r}3 \\
5 \\
\ldots \\
\cdots \\
\text { Well }\end{array}$ & $\begin{array}{c}. . \\
. \\
. . \\
. \\
\text { nted. }\end{array}$ & $\begin{array}{r}97 \\
95 \\
100 \\
100\end{array}$ & $\begin{array}{l}\text { Mar. } 29 . \\
\text { Apr. } 4 \ldots \\
\text { Apr. } 18 . \\
\text { May } 16 . \\
\text { May } 31 . \\
\text { June } 20 .\end{array}$ & $\begin{array}{r}50 \\
24 \\
10 \\
4 \\
3 \\
2\end{array}$ & $\begin{array}{l}\ldots \\
3 \\
\cdots \\
\cdots \\
\cdots \\
\cdots\end{array}$ & $\begin{array}{l}50 \\
73 \\
90 \\
96 \\
97 \\
98\end{array}$ \\
\hline
\end{tabular}

The results point conclusively to the fact that 14 days should be allowed for the cement to set.

\section{Sculdy No. 9, Strc. 28}

The same procedure was again followed in this well, which started to pump water before the flow of oil. At first the well flowed at the rate of $500 \mathrm{bbl}$. per day, but gradually diminished; the average production

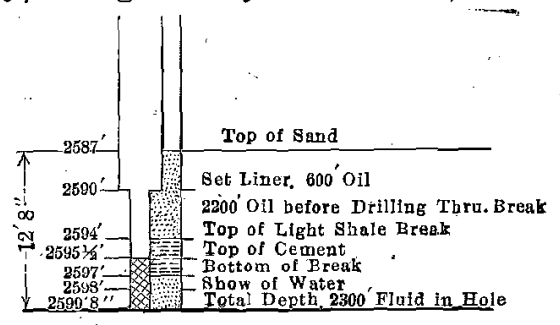

Fig. 3.-Moyle No, 23. Cement and character of sand when drilling in.

during 60 days was $75 \mathrm{bbl}$. The well is now pumping about three times as much water as oil.

\section{Moyle No. 23, Sec. 10}

A good top pay was encountered (Fig. 3), followed by a shale break under which was water. The well was then cemented to $2595.5 \mathrm{ft}$., but this work proved unsuccessful, as the well has produced a high percentage of water since cementing. After testing, the cement was proved 
to be of a poor grade, so that this work has to be done over. Since cementing, the well has produced about 40 per cent. of oil.

\section{Cunningham No. 6, Sec. 16}

This well was cemented April 1, 1918, the top of the cement being at $2491 \mathrm{ft}$. The results are shown in Table 4.

TABLE 4.-Cunningham No. 6, Sec. 16

\begin{tabular}{|c|c|c|c|c|c|c|c|}
\hline \multicolumn{4}{|c|}{ Before Cementing } & \multicolumn{4}{|c|}{ After Comenting } \\
\hline Date & Oil & B. $\mathbf{s}$. & Watex & Date & Oil & B.s. & Water \\
\hline $\begin{array}{l}\text { Sept. } 5,1917 \ldots \\
\text { Oct. } \mathbf{3 1} \ldots \ldots \ldots \\
\text { Jan. } 17,1918 \ldots \\
\text { Mar. } 14 \ldots \ldots \ldots\end{array}$ & $\begin{array}{r}3 \\
3 \\
\ldots \\
\ddot{11}\end{array}$ & $\begin{array}{l}\ldots \\
\ldots \\
\cdots \\
\ldots\end{array}$ & $\begin{array}{r}97 \\
97 \\
100 \\
89\end{array}$ & $\begin{array}{l}\text { Apr. } 25,1918 \ldots \\
\text { May } 7 \ldots \ldots \ldots \\
\text { May } 15 \ldots \ldots \ldots \\
\text { June } 1 \ldots \ldots \ldots \\
\text { June } 13 \ldots \ldots \ldots\end{array}$ & $\begin{array}{l}75 \\
79.6 \\
97 \\
81 \\
84.5\end{array}$ & $\begin{array}{l}\ldots . \\
3.2 \\
2 \\
12.5 \\
1.0\end{array}$ & $\begin{array}{l}25 \\
17.2 \\
1 \\
6.5 \\
14.5\end{array}$ \\
\hline
\end{tabular}

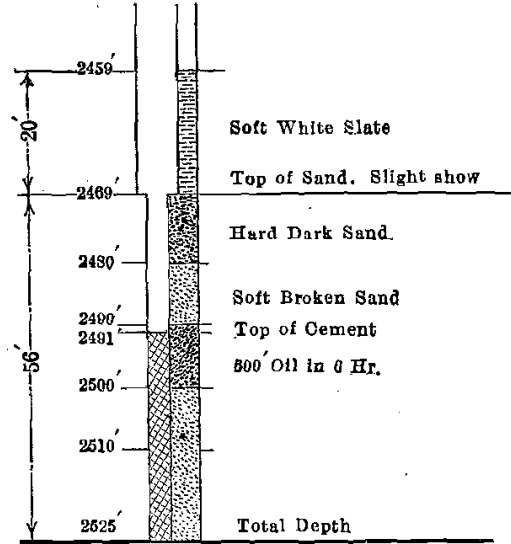

Fig. 4.-Cunningham No. 6. Cement AND CHARACTER OF GAND WHEN DRILLING IN.

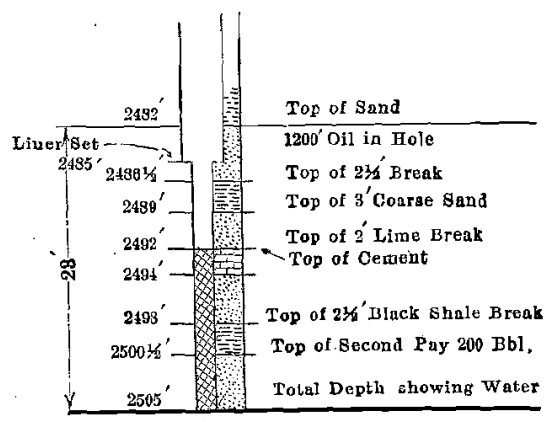

Fig. 5.-Sodlly No. 10. Cement and CHARACTER OF SAND WHEN DRILLING IN.

\section{Souluy No. 10, Sec. 9}

Two pays were encountered, which were separated by distinct breaks (Fig. 5). The second pay showed a little water at the time of drilling. Six days later, one sample gave 100 per cent. water while an average of an 8-hr. sampling tested 72.4 per cent. water. This well was cemented to shut off the bottom pay, and since then has produced very satisfactorily, as shown in Table 5 , yielding 3 to $5 \mathrm{bbl}$. of oil per hour. 
TABLE 5.-Scully No. 10, Sec. 9

\begin{tabular}{|c|c|c|c|c|c|c|c|}
\hline \multicolumn{4}{|c|}{ Before Cementing } & \multicolumn{4}{|c|}{ After Cementing } \\
\hline Date & Oil & B. $\mathbf{s .}$ & Water & Date & Oil. & B. $\$$. & Water \\
\hline $\begin{array}{l}\text { Mar. } 26,1918 \ldots \\
\text { Mar: } 25 \ldots \ldots \ldots \\
\text { Apr. } 10 \ldots \ldots \ldots \\
\end{array}$ & $\begin{array}{l}26.6 \\
\ldots \ldots \\
\text { Well cer }\end{array}$ & $\begin{array}{l}1.0 \\
\ldots \ldots \\
\text { ented. }\end{array}$ & $\begin{array}{l}72.4^{*} \\
100\end{array}$ & $\begin{array}{l}\text { May } 1,1918 \ldots \ldots \\
\text { May } 2 \ldots \ldots \ldots \\
\text { May } 4 \ldots \ldots \ldots \\
\text { May } 6 \ldots \ldots \ldots \\
\text { May } 7 \ldots \ldots \ldots \\
\text { June } 12 \ldots \ldots \ldots \\
\text { June } 19 \ldots \ldots \ldots \\
\text { July } 1 \ldots \ldots \ldots\end{array}$ & $\begin{array}{l}39 \\
98.5 \\
95.1 \\
98.3 \\
97.8 \\
100 \\
98.9 \\
98.5\end{array}$ & $\begin{array}{l}1 \\
0.75 \\
3.0 \\
0.9 \\
1.6\end{array}$ & $\begin{array}{l}0.75 \\
1.9 \\
0.8 \\
0.6 \\
\\
1.1 \\
1.5\end{array}$ \\
\hline
\end{tabular}

*Average of 8-hr. testing.

Miller No. 7, Sic. 2

It was decided to mud the sand before cementing. A packer was placed and a pressure of 500 to $600 \mathrm{lb}$. was applied continuously for three

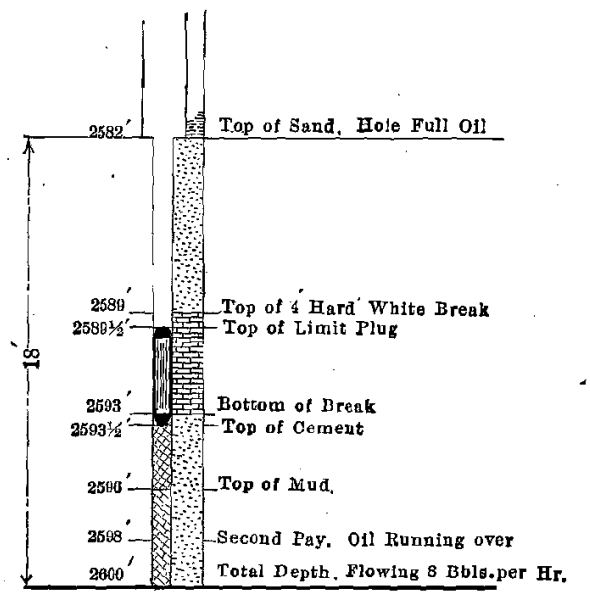

FIa. 6.-MILLER No. 7. ChMENT, LIMIT PLJG AND CHARACTER OF gAND WELLE DRILLING IN.

days. A limit plug was driven in, but did not hold. One-fourth sack of cement was then put in, and a limit plug was driven in it (Fig. 6). The well was allowed to stand for a while and was then pumped. The results before and after were as shown in Table 6.

The results of the cementing of the 13 wells were as follows:

1. Six were very successful, in that the water was shut off in the well itself and production was reclaimed.

2. Four were successful, in that the percentage of water produoed was decreased. One of this number is to be cleaned out and re-cemented. 
TABLE 6.-Miller No. 7. Sec. 2

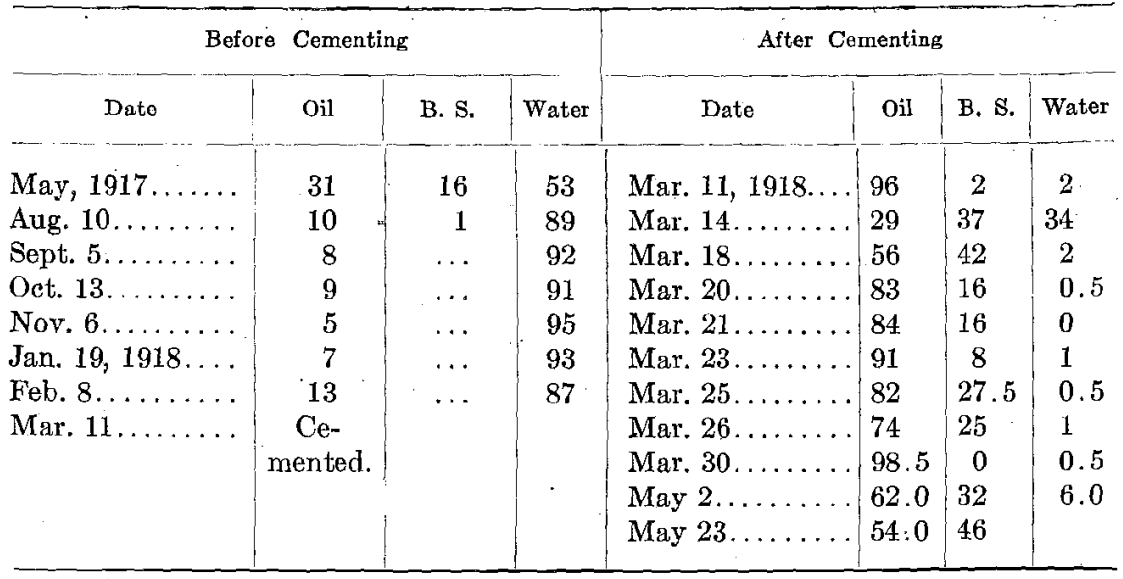

3. One was successful, in that, while the well continued to produce water, it also produced an average of $75 \mathrm{bbl}$. per day for two months. It was producing no oil before cementing.

4. In one well, oil and water were plugged off, and when an effort was made to drill out the cement a strong flow of water was encountered. The sand was so flooded that it was decided to abandon the well. The cementing of this well caused an increase of production in the nearby wells.

5. One was successful, in that the amount of water produced was diminished to a few barrels, and an offsetting well began producing oil.

6. Four of the wells cemented did not give satisfactory results, as the proportions of oil and water produced were practically unchanged. These wells are to be abandoned as non-productive, after it is proved that the sand is flooded.

7. One was a complete failure. The cement was drilled out and the second operation was very encouraging, as an increase of production was noted. This well is to have more work done on it.

8. One well was cemented so high that it has to be drilled out and tested.

9. One well was proved to be no longer productive, and is to be abandoned.

Nine wells have not been tested as yet.

Preliminary attempts to shut off the bottom water by cementing have been successful in most cases. There are certain disadvantages to be considered, although they are generally. overbalanced by the advantage.

\section{Disadvantages of Cementing}

The process may cement oil sand as well as the water.

The well has to be shut down 10 or $\mathbf{1 4}$ days. 
The cement has to be carefully tested for setting qualities.

If but a few feet of sand are to be cemented, generally some means have to be taken to keep the cement from being agitated. Driving a temporary plug and mudding the sand have been tried.

\section{Advantages of Cementing}

The cement assumes the same shape as hole; it does not leave cavities.

There is no pounding or jarring, thus preventing shattering of the sand.

The cement can be partially or entirely drilled out if unsatisfactory. Cement drills about the same as a lime formation.

When pressure is applied the cement will penetrate the sand and seal it.

The amount of cement to be placed can be carefully gaged. One

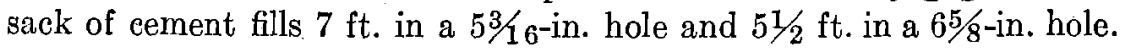

It is estimated that to clean out and cement a well costs $\$ 600$. In all of the successful cases, this cost was returned in a few days. The wells in which production was not reclaimed showed sufficient evidence to warrant abandoning; all casing and other equipment could then be removed.

\section{DISCUSSION}

Mowry Bates, Tulsa, Okla.-In the first part of this paper the author says: "In an unpublished paper on Water Problem in the Augusta Field, S. K. Clark reaches the following conclusions: (1) That the great amount of water present is bottom water, occurring in the Varner sand, the main producing or the 2500 -ft. horizon. (2) That the only striking connection between structure and water is in the area of the marked fault on the Ralston, E. C. Varner, and F. Varner leases in sections $8,9,16$ and $17 . "$

That paper must have been written a long time ago because practically all of the producing wells are in water now and were on structure, that is on the sides of the numerous domes found in the El Dorado and Augusta fields. They are now practically all making water and the water occurs in the lime where the oil is mostly found. The oil is forced out by a hydraulic flow, there is no gas in the producing zone at all. The lower wells strike water first; the ones highest up on the structure will make entirely oil. As the oil is taken out the water flows up the structure. The Shumway lease, of which I suppose you have all heard, has produced up to date enough oil to fill a tank $1 / 2 \mathrm{mi}$. square and $7 \mathrm{ft}$. deep from the porous lime formation, which is more oil than the lime 
usually contains. That lease is practically all water today and I do not see how they can shut the water off by plugging.

Edgene Coste,* Calgary, Alta.-My experience is that in many cases you cannot avoid the water. If the water is in the sand itself, the only thing you can do is not to drill too deep into the sand. If you have drilled too deep, sometimes it is possible to plug the bottom water and in that way so minimize the trouble that the water becomes an advantage, for a little water is really an advantage.

There are two main things to avoid in these water troubles: First, the water from above, to avoid which one must be sure that the casings are tight and set at the right depth; they should be cemented if necessary before drilling into the oil sand. That is an easy thing to do with a little patience and care. Second, the most important thing is to avoid water trouble from the outside of the field. This outside water comes from wells beyond the pool, in the dip mostly, but sometimes not in the dip. The state should intervene on those wells that are just water wells, and should compel the operators to plug a well before abandoning it. The operators themselves inside the fields will easily overcome all the other water troubles which will not affect the total production of the field. Although certain particular leases may get too much water as the oil becomes exhausted, yet the field as a whole will not be affected.

Mowny BATES.-About two weeks ago we asked some of the operators in the Mid-Continent field, who had been plugging the wells, what the effect had been. They said the production was increased for a very short time. But it seems to me that if this oil is produced on an anticline, and it is pretty well established now that it is, and as the pressure is practically hydraulic pressure at the rate of $0.4 \mathrm{lb}$. per foot of depth except in a very few cases of synclinal oil, as fast as you extract the oil the water must ascend. As for plugging a well, you only plug about 7 in. and generally there are about 6 acres around each well through which water can pass. You cannot stop the ascent of the water.

When you take out the oil, the water is going to follow. You can plug an individual well or a dry hole that is making water and save it for a very short time, but only for a short time. That is absolutely proved in the Cushing field, where some of the wells were plugged. The production was increased about 50 per cent. at the time, but it is down again and all the wells make just as much water now as before, though some of them were cemented over. This is true in all cases of the Bartlesville sand but some of the wells that were making water from the Tucker sand have been successfully plugged as there is a break between the sands.

\footnotetext{
*President and Chief Engineer, Canadian Western Natural Gas, Light \& Power Co., Ltd.
} 
A. W. A mrrose,* Washington, D. C.-In California they had very good success in the Coalinga District and elsewhere by coöperation between the companies. As a result, in certain wells that were considered hopelessly gone to water, it was possible not only to shut off the water but to increase the production. When you consider that a driller can never pick up a break of a few inches unless the break has some characteristic feature, I fail to see how it would be possible to pick up a 3-in. shale break at a depth of $2200 \mathrm{ft}$. in a well drilled by a rotary.

Mowny Bates.-While working for the Gulf company, I was authorized to stop a well and test it. I washed it out for about $2 \mathrm{hr}$., then moved the bit for 5 or $10 \mathrm{~min}$., and then washed it again. It cost the company a lot of money, but I was trying at that time to get some samples for the Geological Survey.

A. W. Ambrose.-Another way is to put a core bit on the bottom of your rotary drill pipe; otherwise, I do not see how, when you wash, where you have 2000 or $3000 \mathrm{ft}$. of open hole, you are going to pick up such a small shale break, as the shale above may cave in and show in the washings. Take the Eldorado Augusta case: Many of the companies have no record but the thickness of the oil sands. They do not know, for instance, whether in the 50 -ft. producing horizon there are one, two, or three breaks or one unbroken producing horizon. The companies there have everything to gain and nothing to lose by coöperation, which has proved very suce ' in California. In the Kern River field, some wells were producing as Ligh as $15,000 \mathrm{bbl}$. of water per day by the aid of air compressors in order to get 40 or $50 \mathrm{bbl}$. of oil. Some of these compressors must have cost anywhere from $\$ 200,000$ to $\$ 300,000$. When the compressors were first used, operators lifted a small quantity of water; then the flow of water increased as the flow channels in the sand opened and soon the old compressors had to be replaced for newer and larger ones. By cooperating and spending about $\$ 5000$ to trace the source of that water and connecting one well, it was possible to junk several thousand dollars worth of compressors.

I. N. KNAPP, $\dagger$ Ardmore, Pa.-My experience is that it is bad practice to wash out a well at any particular point to determine the formation. It is extremely difficult in rotary drilling to get reliable samples of the material as it is passed through. If clear or turbid water is used, the cuttings tend to dissolve or separate by the jigging action of the ascending circulation, and the heavy particles tend to lodge in the irregularities in the walls of the well between the end of the casing and the bottom of the hole. In such cases it is very difficult to find any

* Petroleum Technologist, U. S. Bureau of Mines.

$\dagger$ Mechanical Engineer. 
material in the overflow from which to judge of the formation through which the drill is passing. If a heavy mud is used there is much less dissolving, separating and mixing of the drill cuttings, and on washing out a sample from the mud overflow, particles may be found that fairly indicate the material just drilled through.

If you wish to get an accurate well log with samples of an unconsolidated formation at any particular horizon with the rotary it is necessary to take a core. This is a pretty hard proposition but I have accomplished it. I have taken out as much as $12 \mathrm{ft}$. of core at a time. It is difficult to get a soft core out of the core barrel and lay it out on the ground without considerable breakage, but I did get some pieces 2 and $3 \mathrm{ft}$. long. The material was very friable and easily broken with the fingers.

I have been told of a device that has been in practical operation in the Baku, Russia, oil field for some time that will pick up an accurate sample of the formation from the walls of wells drilled in unconsolidated formations at any selected point between the end of the casing and the bottom of the well. Such a device is greatly needed in this country.

I have had top and bottom water troubles in fields where the oil sands themselves were saturated with oil only and this without a trace of water. If the top water in such cases was efficiently shut off in the first place there was no future trouble. The bottom water after once being definitely located could not cause trouble unless deliberately drilled into. We have heard a great deal about water in the same sand with the oil and of mudding and cementing this afternoon but no reference has been made to Texas and Louisiana conditions and practice. What has been said does not seem to agree with the practice down there.

Mowny Bates.-I would like to return to what Mr. Ambrose has said. I cannot see why plugging one well is going to shut off 6 or 7 acres of sand. It will shut off the water up to the level of the oil, but as the oil comes out the water comes up.

A. W. Ambrost.-We are arguing on different points. You are assuming that the water occurs in the oil sand while I am assuming that it may not be.

Mowny Bates.--It is in the Mid-Continent field.

A. W. Ambrose.-That same thing was contended by the oil operators in California until they were shown.that there was a separation between the oil and the water sands. When they plugged off the water, they found there was a break that had never been considered, and the point is whether or not similar conditions hold in Augusta.

Mowry Bates.-I do not think they do. 
I. N. KNAPP. - A bulletin recently issued by the Smithsonian Institution $^{1}$ contains a section on petroleum and a section on natural gas. The writcr of the petroleum section claims that so long as the ownership of oil in the ground is determined by vertical property boundaries, arbitrarily dividing a geologic unit or reservoir into many parts, just so long will there be hurried production with all its train of waste and losses. The writer of the natural=gas part claims gass-field operating conditions should be regarded as a natural monopoly and that it is a primary need of the industry to have mandatory pooling of field operations, coupled with an adequate market price.

It would be a fine thing for the operator to individually control all the land in any one oil or gas pool or reservoir. It would ultimately result in the landowner getting more royalty and in the conservation of both oil and gas and also lower the cost of production. I am fearful that all the oil and gas in our country will be exhausted before such conditions can be brought about.

Eugene Coste.-The great trouble of water in the oil and gas fields is due to the careless man, the one who wants to pull out his casings and sell them, or the one who relies too much on the drillers and does not assure himself that the casings are properly set in the right place, and properly. cemented when nccessary. A careful operator will take the necessary precautions to have his casings right but when a careless man on another lease does not case off properly, he communicates the different water sands with the oil sand either from above or below. I think the sands from above are especially dangerous. When a man pulls out all his casings and does not have his well properly plugged, the greatest danger is from the fresh-water sands. The fresh water from above is the most dangerous because it gets the weight of the thousands of feet between the surface and the oil sand, which can of ten easily overcome the pressure in that sand.

I entirely agree with the gentleman who recommends coöperation among the operators, but would include also coöperation and regulation by the state-regulation by an authority that can make the operator give the proper information to the inspector so that he can do his work intelligently. If that is done, it will save millions of dollars worth of oil.

Even after a field has been used for many years, no strong hydraulic pressure is found to interfere with production. We know that absolutely because gas fields with original pressures of, say, $1000 \mathrm{lb}$. have had very little trouble with water, when the proper precautions were taken, even when the pressure had declined to $50 \mathrm{lb}$. in the field, and even down to nothing.

${ }_{1}$ See Smithsonian Institution, United States National Museum, Bull. 102, Pt. 6. Petroleum: A Resource Interpretation; Pt. 7. Natural Gas: Its Production, Service and Conservation. 
The Chairman (David White, * Washington, D. C.).--The use of the terms "primary" and "secondary" as incorporated in this paper tends to create confusion on account of the use of the terms in the discussion of the chemical composition of oil-field waters. However, in attempting to suggest substitutes, one encounters the difficulty of length and cumbersomeness of such substitute terms as indigenous or axutochthonous, but he might use foreign and native waters.

I feel that the studies which have been made from the chemical standpoint of the oil-field waters-G. S. Rogers is carrying on such studies now-tend to show great value in the analysis of the waters with reference to detecting their origin. Top waters, such as those described, should be readily identified by their analyses.

*U. S. Geological Survey. 